NBER WORKING PAPER SERIES

\title{
MARKET EVALUATIONS OF BANKING FRAGILITY IN JAPAN: JAPAN PREMIUM, STOCK PRICES, AND CREDIT DERIVATIVES
}

\author{
Takatoshi Ito \\ Kimie Harada \\ Working Paper 9589 \\ http://www.nber.org/papers/w9589 \\ NATIONAL BUREAU OF ECONOMIC RESEARCH \\ 1050 Massachusetts Avenue \\ Cambridge, MA 02138 \\ March 2003
}

The authors wish to acknowledge the financial assistance of a research grant provided by Institute of Economic Research, Daito Bunka University and the ratings history data provided by FITCH Ratings. The views expressed herein are those of the authors and not necessarily those of the National Bureau of Economic Research.

(C2003 by Takatoshi Ito and Kimie Harada. All rights reserved. Short sections of text not to exceed two paragraphs, may be quoted without explicit permission provided that full credit including $O$ notice, is given to the source. 
Market Evaluations of Banking Fragility in Japan:

Japan Premium, Stock Prices, and Credit Derivatives

Takatoshi Ito and Kimie Harada

NBER Working Paper No. 9589

March 2003

JEL No. G10, G15, G21

\begin{abstract}
This paper investigates movements of market indicators of banking fragility, namely, Japan premium, stock prices, and credit derivative spreads of Japanese banks. Although the Japan premium in the euro-dollar market seemed to have virtually disappeared since April 1999, credit and default risks of Japanese banks has not necessarily disappeared. Other indicators show varying degrees of fragility among Japanese banks in 1998-2001. Banking stock prices continue to slide compared to the market-wide stock price index. From pricing of credit derivatives, default probabilitie of banks can be etracted. Correlations among indicators were high both in the first period and in the second period; Credit default swap (CDS) premium explains Japan premium with a significant, positive coefficient. The higher the CDS is, lower go the stock prices. Before the capital injection of 1999, the markets were more sensitive to bank vulnerability and higher premiums were required.

Takatoshi Ito

Research Center for

Advanced Science and Technology

The University of Tokyo

4-6-1 Komaba, Meguro-ku

Tokyo 153-8904 Japan

and NBER

ITOINTOKYO@aol.com

Kimie Harada

Department of Economics

Daito Bunka University

Takashimadaira 1-9-1, Itabashi

Tokyo 175-8571 Japan

kimie@ic.daito.ac.jp
\end{abstract}




\section{Introduction}

The Japanese banking system has been in turmoil since the mid-1990s. Several mid-size banks failed in 1995, and three major banks failed in 1997-1998. These failures prompted a major overhaul in bank supervision: The government blanket guarantee was given to all types of deposits, capital injections to large banks were carried out, and a financial supervisory agency was established and reorganized, in 1998-1999. After some tranquility from April 1999 to late 2001, the bank vulnerability became apparent in 2002 . This paper will investigate how different market indicators, Japan premium, stock prices, and credit derivative spread, have been warning vulnerability of Japanese banks from 1998 to 2002 . An analysis of credit derivative spread will be shown to be a most reliable indicator of credit risk of banks.

Japanese banks have been plagued by several problems since the early 1990s. ${ }^{1}$ First, the sharp declines of asset prices made many borrowers in the real estate and construction sectors insolvent. In the beginning stage of the problem, banks continued to lend to these companies so that they can make interest payments. Even after problems became so large, banks were quite reluctant to force nonperforming customers to fail. Second, the prolonged recession, with the growth rate being one percent, produced many more nonperforming borrowers in many sectors of the economy. Third, overextended businesses of banks

\footnotetext{
1 Previous studies of the bad loan problems, the financial fragility and crisis in the Japanese financial system in 1990s are vast. See for example Horiuchi (1999a) Cargill (2000), Ueda (2000) and Posen (2001).
} 
themselves became costly. Many banks had to retreat from overseas operations. Fourth, Japanese banks traditionally hold equities of their customers and group companies. When the Nikkei 225 index peaked in 1989 just shy of 40,000 yen, the banks were sitting on large unrealized capital gains, that helped to boost the capital adequacy ratio standard. During the first half of the 1990s, the stock prices were hovering at around 20,000 yen, and unrealized capital gains shrank, but still positive. However, when the stock prices further went down below 10,000 in 2001 , equity portfolio started to carry unrealized capital losses, lowering the capital adequacy ratio.

As the bank balance sheets have become damaged, the market started to discriminate against Japanese banks as a whole. Japan premium is a well-known phenomenon. The premium is the extra basis points that Japanese banks had to pay in the offshore interbank market to borrow the US dollar market, and to lesser extent in the yen market. The premium has varied across Japanese banks, and they have also fluctuated over time. Whenever the Japanese banks were judged to be vulnerable, the market charged the Japanese banks an extra premium. Japan premium became a topic of conversation in 1997, after Hokkaido Takushoku Bank failed. Since the government had said that it would not allow any of the major twenty banks to fail, the Hokkaido Takushoku Banks's failure was greeted by a surprise. The market realized that some other Japanese bank could fail without much warning. Peek and Rosengren (2001), Ito and Harada (2000), Horiuchi (1999) and Hanajiri (1999) regard the Japan premium as market indicator of investors' anxiety about the soundness of Japanese 
banks to show how the markets responded.

Then, two banks became in trouble in 1998. The Long-term Credit Bank (LTCB) became rumored to be very weak in the market, due to large nonperforming loans. The new law had to be drafted and passed before the bank was nationalized on (DATE), 1998. Then, the Nippon Credit Bank (NCB) was declared in December 1998 by the regulatory authority to be nationalized.

In order to help calm the situation, and strengthen the capital base of banks, the government decided to inject public funds into banks. In March 1999, 7459 billion yen was injected as preferred shares and subordinated debts to strengthen capital base of banks. The Japan premium all but disappeared and many thought that Japanese banks were on the track to recover. Increasing stock prices in 1999-2000, later known as an IT bubble helped the banks' balance sheets. But, in 2001-2002, the bank fragility has become the issue again. First, When one department store, Mycal, applied for rehabilitation, the bank had to increase its provisioning, because the company was classified only as doubtful. This raised a concern on the banks' lax standard for classifying loans. Second, deferred tax credit have been counted toward capital. Provisioning by banks have been made from taxable income, and tax credit will be given in the following five years if banks earn enough profits to be taxable. Deferred tax credits now occupy one half of the capital that is counted toward capital adequacy ratio. (See for 
example Kashyap (2002) 2). Third, stock prices have been declining, and affecting banks' balance sheet where many equities are held. ${ }^{3}$

The increase in Japan premium is limited. One theory is that Japanese banks are now required to post cash collateral for interbank borrowings. Collaterals can be offset against any losses that may be incurred if a bank defaulted on loan for any reason. Another theory is that counterparties to Japanese bank interbank borrowings are now confident that even when a Japanese bank is declared to be failed, the regulators will quickly take over and honor any liabilities to avoid a cascade of defaults.

In general stock prices reflect also the possibilities of default, as well as discounted future cash flows. Since stock prices also reflect general conditions of the macro economy, an appropriate measure of bank vulnerability would be the difference between the change in the bank stock price and the change in the market-wide stock price index. Our approach of using stock prices is different from those that used stock prices as one of the indicators to show the possibilities of default. Sato et al. (1990) was the first that utilized option model to examine default risk of Japanese banks. ${ }^{4}$

2 Kashyap (2002) provides a description of the issue, bank capital permitting to include tax.

${ }^{3}$ When middle-size brokerage Sanyo Securities went bankrupt in the beginning of November 1997, it was the first firm ever to default on the interbank market and brought a crisis. Since then, gavernment protected all interbank liabilities to avoild such a crisis.

4 The intention of Sato et al. (1990) is not to evaluate default risk itself but the Japanese deposit insurance scheme and discussion of safety net as an insurance system. 
Another measure of bank vulnerability has attracted attention recently. The credit derivatives are the instruments for possible default of credits. The credit derivatives of Japanese banks have been traded, mainly by non-Japanese financial institutions, and their spreads over sovereign Japan is a meaningful measure for possible bank failure. Even if interbank liabilities may be honored, either by collateral or regulator, credit derivative payments will be triggered. Since default or failure is the triggering event, credit derivative spread seems to represent the credit risk most accurately among the three indicators.

Credit risk is the probability that a borrower will default on a commitment to repay debt or bank loans. It is influenced by bank-specific events and economy-wide events. Any news that affect market and banks will influence perceptions on credit risk. A broad measure of a bank's credit risk is its credit ratings (see appendix table1). However, credit ratings are not observable in the daily basis. A more frequent quantitative measure of credit risk is the credit risk premium. The credit premium measured in this paper is the difference between the credit default swap of individual banks and that of Japanese sovereign credit.

The contribution of this paper is as follows: This paper examines the relationship among three indicators that are relevant to measuring health of the banks: Japan premium, stock prices, and credit derivative spread. To our best knowledge, this paper is the first to analyze systematically behavior of credit derivative spread for individual banks.

Japan premium represents default risk in the interbank market. It is closely related to risk of bank failure, but a failure may not necessarily result in non-payment of interbank 
obligation. Either by having collateral or by regulator's intervention, interbank obligations may be carried out even in the event of bank failure. This possibility is more likely in 2000-2001 than 1998-1999. Therefore analysis of Japan premium after 2000 is structurally not comparable to that of 1998-1999, the highest period of Japan premium. Stock prices are another indicator for bank soundness and profitability. However, unless it becomes too low, ups and downs of stock prices reflect more of changes in profitability forecasts rather than changes in perception of default risk. In terms of the reasons described the above, examining the relationship between the Japan premium and stock price movements that Ito and Harada (2000) are looking is not useful methodology in recent years.

In contrast, credit derivatives directly measures credit risk. Credit derivative spread is a best measure of market assessment on how likely a bank is going to fail in a specified time horizon. Therefore, this paper is unique in its exploiting a good data set in looking at changing vulnerability of Japanese banks from 1998-2002.5

To anticipate conclusion, we will find in this paper the following results.

(1) Correlation between indicators were much higher than expected not only in the first period, even in the second period;

(2) Credit default swap (CDS) premium in the JP (Japan premium) equation has a positive

${ }^{5}$ Neal (1996) is the first in explaining the credit derivatives market's development in the early 1990s in the U.S. In it, it is explained how credit derivatives as new financial instruments for controlling credit risks is available. 
and significant impact;

(3) The sensitivity of JP (Japan premium) with respect to CDS became much smaller in the second period, confirming that there was some changes in the LIBOR market perception about the liability protection in the event of bank default;

(4) CDS premium in the stock equation also has a negative and significant impact;

(5) Before the capital injection of March 1999, in the first period, the markets were more skeptical and increased premiums.

\section{Data Description}

\subsection{Three indicators}

Default risks of Japanese banks appear in the three indicators: (1) Japan Premium (interbank borrowing); (2) Credit derivative (credit default swap); and (3) Bank stock price. However, each indicator may show different (combinations) of risk. Increased risk of default will raise (1) and (2) and decrease (3).

Credit derivative is the most direct way to measure credit risk, since it is pricing the default event. Stock prices reflect the residual values of company assets as well as future discounted cash flows. Even if the event of failure is remote, stock prices fluctuate due to changing prospects of profitability, reflecting both market - and economy-wide shocks as well as individual bank shocks. LIBOR premium reflect the probability of interbank default. Interbank default may occur to a solvent bank, if, for some reasons, a bank cannot obtain 
(dollar or yen) liquidity. On the other hand, interbank liability may be protected even in the event of bank failure. Interbank credits may have higher priority in repayments than equity stake holders.

Japan premium became highlighted as an indicator of Japanese banks' vulnerability in 1997-1998. Western banks required higher interest rates when Japanese banks wanted to borrow in the offshore interbank market. The premium was much higher in the US dollar interbank market. This was thought to reflect the risk that Japanese banks would not be able to obtain enough dollars to repay the interbank loans, as their bank soundness was questioned as well as the outright possibility of bank failure. In 1997 and 1998, Japanese banks had to pay nearly 100bps more than US and European banks to borrow dollar.

When vulnerability of Japanese banks reappeared in 2001-2002, there was no significant increase in LIBOR rate for Japanese banks. The magnitude of Japanese premium in 2001-2002 was less than most 10 basis point. However, the low Japan premium does not necessarily prove that the markets are less pessimistic about Japanese banks this time compared to in 1997-98. First, weaker banks disappeared from data or exited form the market, either by withdrawing from the market or by being merged with other healthier banks. Second, even for the remaining banks, they are required to put up cash collaterals to obtain interbank funds. Collaterals protect creditors from losses even in the event of counterparty (Japanese bank) failure. Third, even in the three cases of the Japanese banks failure in 1997-98, interbank obligations were repaid promptly. The western banks may be optimistic 
about Japanese regulators' competence and willingness to carry out interbank obligations promptly.

\subsection{Japan Premium}

The Japan premium is a premium imposed on Japanese banks' borrowing rate by U.S. and European banks in the Eurodollar and euroyen market. It reflected counter-party risk based on the western banks' belief that Japanese banks had higher risk of default. In Ito and Harada (2000), the Japan premium is defined as the difference between the Eurodollar TIBOR (the Tokyo interbank offered rate, or the Eurodollar interbank borrowing rate in Tokyo) and the Eurodollar LIBOR (the London interbank offered rate, or the Eurodollar interbank borrowing rate in London) since it is viewed that the Japan premium emerged in the Eurodollar market the most.

It reflects counter-party risk based on the western banks' belief that Japanese banks had higher risk of default, especially in the dollar market. In particular, the dollar liquidity was a concern at the time of the 1997-98 crisis. In this paper, Japan premium is defined as the difference between the interbank euroyen rate quoted by Japanese banks and the average of the rate quoted by the non-Japanese banks in the euroyen LIBOR samples. The reason we used Euroyen rate rather than Eurodollar rate is availability of samples. Sample banks are very limited if Eurodollar market is examined.

Japanese banks use cash collaterals in interbank transactions since 1999 Spring. It 
is said that default risk might not appear in the Japan premium since then. We define the

Japan premium as the following form;

$$
J P_{i t}=L I B O R 3 M_{i t}-\operatorname{LIBOR} 3 M_{t}
$$

where $J P_{i t}$ is the Japan premium of bank $i, L I B O R 3 M_{i t}$ is the euroyen 3 month interbank rate quoted by bank $i$ and $L I B O R 3 M_{t}$ is the euroyen 3 month market rate at time $t .^{6}$

\subsection{Credit Derivatives 78}

Credit derivatives are over-the-counter financial contracts that have payoffs contingent on charges in the credit of a firm. It also reflects default risk. Credit default swap (CDS) are financial contracts that provides insurance against credit-related losses.

Credit derivatives, the US dollar denominated default swap, are the average of offer and bid rates posted by brokers at the close of the Tokyo market. $910 \quad$ When both bid and offer

\footnotetext{
6 The euroyen LIBOR is calculated by the British Bankers' Association as the average of the yen interbank offered rates. Although the premium in the dollar market was serious rather than that in the euroyen market as described in Saito and Shiratsuka (2001), euroyen LIBOR is used in this paper since the sample Japanese banks in the euro dollar is very limited.

7 We wish to acknowledge kind help by Mr. SAEKI Nobukazu of Mitsubishi Tokyo Financial and Ms. KAWAI Yuko of RP Tech for their answering our questions on the structure of the credit derivatives market.

8 The market size is based on the officially surveyed statistics, the so-called Yoshikuni Statistics, of the Bank of International Settlements, presented in Appendix Table 4.

9 Japanese credit derivatives market has started around the beginning of 1998 . This was a relatively late start, however the market has been growing very fast. Most products traded in the market are credit default swaps. The default swap premium is the cost of a credit risk. The investor who wants to avoid the risk is called "protection buyer "(risk seller) and pay a premium to be protected in case of credit event affecting the reference entity. While the protection seller (risk buyer) receives the premium. Protection seller (risk buyer) has to pay obligations to the seller if a credit event
} 
are missing for day $t$, then data of day $t-1$ is substituted in. When one of a bid or an offer is missing, the value is substituted between observation days so that the bid and offer would not be reversed. When missing days continue for a couple of days, we eliminated the period form our samples. However, these days were not observed often since June 1998. The original data are taken for all days when both offer and bid are shown by brokers. Samples are for the Bank of Tokyo-Mitsubishi (later Mitsubishi-Tokyo Holding), Fuji Bank, Daiichi Kangyo Bank, Industrial Bank of Japan (later those three becoming Mizuho Holding), Sanwa Bank (later UFJ Holding), Sumitomo Bank (later Sumitomo-Mitsui Bank), and Sovereign Japan. ${ }^{11}$

Credit derivative spread extracting Japanese bank's provabilities of default risk is;

$$
C D S_{i t}=B A N K_{i t}-J A P A N \text { sovereign }{ }_{t}
$$

where $C D S_{i t}$ is the credit derivative spread of bank $i, B A N K_{i t}$ is credit default premium of bank $i$ and $J A P A N$ sovereign ${ }_{t}$ is sovereign premium at time $t$.

\subsection{Bank Stock Prices}

Bank stock price movements relative to market index, the difference between the two, are

occurs.

10 There are several specificities in the credit derivatives market in Japan. One is the definition of credit events. ISDA Credit Derivatives Definitions in 1999 clarify credit events, however "nationalization" of a Japanese bank is not confirmed.

11 Our sample period reflects the availability of the CDS data since the market has started in the beginning of 1998 . 
defined as to express bank's risk of default. The difference would be that;

$$
\text { STOCK }_{i t}=\log (\text { stock })_{i t}-\log (\text { TOPIX })_{t}
$$

where $\operatorname{STOCK}_{i t}$ is the log difference of bank $i$ 's stock price and market index TOPIX $t$ at time $t$. The movement of specific bank stock price relative to other sectors can be examined. We construct specific bank stock price excluding other sectors by subtracting TOPIX from individual bank stock. That is, excluding general movements in the stock market, TOPIX, we can construct bank stock price movements.

\section{Correlation among Three Indicators}

\subsection{Bank Mergers and Sample Break}

Although we cover the period from June 1998 to September 2002, there was a major change in the scenery of Japanese banking. After mergers of several banks and trust banks, the four major banking groups emerged. Due to the mergers, some banks are not comparable before and after these mergers. Therefore we break the sample into two, the First half: from June 1998 to September 1999, and the second half: from April 2001 to September 2002. The big four financial groups were formed in the aftermath of the 1997-98 banking crisis.

In September 2000, the Dai-Ichi Kangyo Bank, Fuji Bank and Industrial Bank of Japan established the bank holding company, "Mizuho Holdings, Inc." There are three banks under the holding company in 2002, the Mizuho Corporate Bank, the Mizuho Bank and the Mizuho trust and banking. 
In April 2001, the Bank of Tokyo-Mitsubishi, Mitsubishi Trust and Banking, Nippon Trust Bank and Tokyo Trust Bank established the bank holding company, "Mitsubishi Tokyo Financial Group,Inc." Three trust banks merged in October 2001. The group is dominated by the commercial bank, and since it did no involve a merger of commercial banks, there is continuity in the commercial banking part.

In April 2001, "UFJ (United Financial of Japan) Group" was established by the Sanwa Bank, Tokai Bank and Toyo Trust and Banking. The two commercial banks, Sanwa and Tokai, merged into UFJ Bank and Toyo Trust and Banking changed its name to UFJ Trust Bank in January 2002. Sanwa is a nation-wide commercial bank, with emphasis in Kansai region, plus some international businesses, while Tokai is a bank based in Nagoya region.

In April 2001, "Sumitomo Mitsui Banking Corp. (SMBC)," was established by a merger between the Sakura Bank and Sumitomo Bank. This was straight-forward merger of two competing banks with similar nation-wide branch networks. The two banks were at the core or respective corporate groups, which have roots in pre-war zaibatsu. In this sense, the merger of the two banks put pressure on mergers of non-financial corporations in the two corporate groups too.

These mergers and reorganizations are summarized in Table 1.

Insert Table1 about here

\subsection{Three Indicators for each bank}


Three indicators for each bank are shown in Figure 1 (Panels 1-1 to 1-6) for the first period and Figure 2 (Panels 2-1 to 2-2) for the second period. Stock represents level of bank stock price, LIBOR (In the figures, LIBOR is denoted by LIBOR 3.) is the Japan premium described in 2.2, the difference between individual bank's euroyen 3 month interbank rate and market rate, and CDS is representing credit derivative spread, credit default premium of bank $i$ minus sovereign premium as in 2.3. LIBOR in the figures is ten times larger than original level for convenience.

Insert Figures 1-1 to 1-6 about here

In the first period, three indicators of all six banks show a similar time-series pattern. (1) Japan premium (LIBOR) shows quite dramatic increase from June to November 1998, and then decreased gradually April 1999. (2) Credit derivative spreads show a similar pattern, but peaking slightly earlier than LIBOR and decreased more gradually than LIBOR. (3) Stock prices had a sharp decline from June to September/October 1998, and then started to recover. After April 1999, all indicators are more or less calm. (4) Japan premium and CDS basically disappeared after April 1999, when the second capital injection was completed, except Fuji, IBJ, DKB seemed have return of high LIBOR in the summer and fall of 1999. The correlations among the three indicators seem to be fairly high between June 1998 and April 1999.

An examination of these three indicators reveals that the market had discriminated quality of these banks. The indicators tend to agree on the health of banks.

(1) In the first period, Fuji Bank was regarded by the market as the riskiest among the six. It 
had highest LIBOR, highest CDS, and most stock price decline. In the second period, Mizuho was the worst in terms of the stock price change, the peak level of LIBOR (tie with UFJ), and in the peak level of CDS. (2) The market regarded the Tokyo Mitsubishi as strongest among the six in the first period and among the four in the second period. In all of the three indicators in both periods (except in stock price decline in the first period), the Tokyo Mitsubishi Bank is the best. (3) Timing of the peak in LIBOR and CDS, and also the trough in stock prices tend to coincide for all banks. This indicates that a shock to the banking sector was common, but vulnerability or sensitivity to the shock was different among different banks.

\section{Insert Figures 2-1 to 2-4 about here}

In the second period, CDS has increased markedly in December 2001 for all four financial institutions, Mizuho (spread of up to 204.5), Mitsubishi Tokyo (120), UFJ (192), and Mitsui Sumitomo (145.5). Stock prices had declined steadily from the spring of 2001 to February 2002. The degree of decline was the most for the Mizuho (72.8\%) and UFJ (70.1\%), and the least for Mitsubishi-Tokyo (43.5\%).

\section{Insert Table2 about here}

The soundness evaluated by the markets did not change even after most major banks consolidated and formed four financial groups. The Tokyo Mitsubishi Bank has been the best and Fuji, current Mizuho, has been the riskiest, according to the market.12

12 The capital ratios of banks disclosed publicly were all above a critical mark of $8 \%$ and differences among banks were not significant. However, market participants might not have trusted these 


\subsection{Correlation Analysis}

Table 3 presents statistical summary of the levels of stock prices, LIBOR, and CDS. The table reveals the following characteristics of these market indicator movements. Those banks that had high CDS values (max and average) in either first or second period tended to have higher LIBOR (average and max) levels and a sharpest drop in stock prices ((max - min)/average). The averages of LIBOR and CDS were smaller in the second period except CDS of DKB and IBJ. The averages of CDS for DKB and IBJ were smaller before their merger, but those of two banks become larger in the second period. The ranges for LIBOR and CDS were much smaller in the second period than those in the first period. The standard deviations ("s,d." in Table 3) of LIBOR became smaller in the second period, but standard deviations of CDS did not change over time.

The worst bank in terms of CDS average was Fuji Bank in the first period, and Mizuho Bank in the second period. The Mizuho is a product of a three way merger of Fuji, IBJ and DKB. The three banks were the weaker three of the six in the first period. A merger of three weaker banks turned out to be one large weak bank, at least in the eyes of the market.

numbers. The number included differed tax credit and capital injected by the government in 1998-1999. The adjusted capital ratios were widely circulated by research publications of investment banks and securities firms as well as academic work. Appendix 2 and appendix 3 of this paper show that Tier1 capital adjusted for the deferred tax assets (the equity equivalent in excess of differed tax assets) and preferred shares. Excluding deferred tax assets in Tier 1 capital reduces the banks' regulatory capital ratios substantially, especially in 2002 . 
Insert Table 3 about here

Next, correlation coefficients among the three indicators are examined. The stock prices and credit derivative spread are expected to be negative. This is confirmed in the time of bank turmoil. However, during the period of IT bubble, from 1999 to spring of 2000, stock prices of banks rose more than the market average, because banks hold a wide-range of stocks including IT-related stocks. The CDS, representing credit risk, behaved differently from stock price movements. The market participants of the credit derivatives were not impressed by the stock price increases.

Insert Table 4 about here

The correlation of the LIBOR and CDS are shown in Table 5. The correlation is expected to be positive, as both represent the vulnerability of bank financial health. This prediction is confirmed in the data.

The correlation coefficient in the first period is uniformly higher than those in the second and third periods, suggesting that LIBOR3 represented credit risk more in the first period. As suggested earlier in the paper, LIBOR3 lost direct relationship to credit risk after April 1999, because either collaterals are used or counter-parties believe interbank liabilities would be honored even in the case of a bank failure. ${ }^{13}$

13 This information is obtained from the hearings we had with market participants. "Collaterals" do not mean those under CSA (Collateral Support Annex, which is official transaction based on the regulation of ISDA), but collaterals here are part of the swap arrangement where the Japanese yen is used in the swap transactions in order for Japanese banks to obtain the U.S. dollar for a certain period. The "Japanese premium" is hidden in the interest rates used in this swap arrangement. 
Insert Table 5 about here

Banks that are rated to be weak tended to have higher correlation in the second half period, especially in the relations of stock prices and credit derivative spread (-0.807 for Mizuho, -0.903 for UFJ, -0.821 for Sumitomo Mitsui and -0.283 for BTM. Long-term credit ratings for Mizuho, UFJ and Sumitomo Mitsui were single "A" that of BTM was "A+" at the end of March 2001.).

\section{Panel Analysis}

The panel regression is conducted in the following form. Dependent variable is either one of the following:

$$
\begin{aligned}
& J P_{i t}=L I B O R 3 M_{i t}-\operatorname{LIBOR} 3 M_{t} \\
& \text { STOCK }_{i t}=\log (\text { stock })_{i t}-\log (\text { TOPIX })_{t}
\end{aligned}
$$

As an independent variables, we use the following variables; CDS, Call rate and a dummy variable, where they are defined as follows: $C D S_{i t}=B A N K_{i t}-J A P A N s o v e r e i g n_{t}$, Call $=$ Call rate, uncollateralized overnight. ${ }^{14}$ For the interest rate, we use daily observations of the overnight uncollateral call rate, data being taken from the Toyo Keizai Monthly Statistics.

14 We have examined panel regressions with a dummy variable that takes 1 before the second capital injection, March 1999, and 0 after April 1999. The regression results were almost the same as the results presented in this paper. The dummy variable was included to control for a possible regime change in bank financial soundness however the regression results are not shown because of the following econometric reason.

As long as a dummy variable is used in the panel regression, fixed effect model has a bias. For the level data we use in our regression, fixed effect model is preferable since it brings us the same effect as the panel regressions in differenced form. 
Both CDS and Call are expected to correlate positively with the Japan Premium and negatively with the STOCK. Call rate is proxy for monetary policy so that an increase in call rate implies the tighter monetary policy and liquidity in the market, and it may lead to a higher possibility of bank failures.

Tables 6-1, 6-2 and 6-3 report results of a panel analysis. The regression results of OLS, with the fixed effect estimators, are reported in Table 6-1. Stock prices are affected negatively by CDS, and the coefficient is statistically significant. The Japan premium tends to be higher when the CDS is higher, and the coefficient is also statistically significant for both of the periods. In equations (1) and (2), that examine whether CDS, as the fundamental default indicator, influences stock prices and the Japan premium. The impact of CDS on the Japan premium in the second period is about one eighth of that in the first period $(0.101$ for the first half and 0.013 for the second half). This evidence is consistent with our conjecture that the Japan premium became very small in the second period, because collateral is used or because market participants believe that a failure does not imply default in the interbank market. The impact of CDS on STOCK has increased (larger coefficient in magnitude) in the second period ( -0.0003 for the first half and -0.001 for the second half). In fact, the size effect of coefficients of CDS in the second period is about four times larger than that of the first period. Stock prices, representing profitability, is more sensitive to the default risk in the second period. Therefore, unlike the Japan Premium, the default factor in stock prices has increased in the second period compared to the first period. The signs of call rate sometimes are not consistent with our 
priors.

Insert Table 6-1 about here

Table 6-2 and Table 6-3 present the results of the OLS, pooled and the random effect estimators respectively. Most of the results of Table 6-1 carry over to Tables 6-2 and 6-3. The sensitivity of stock prices to CDS is similar for the first sample period, and they are negative and significant, and smaller in the first period. That of the Japan premium to CDS is also the same. It is positive and significant for the first and second period, and much smaller in the second half.

An important finding of the Japan premium becoming insensitive to CDS is robust against different methods of panel regression. A conventional wisdom in the market, that is, the Japan premium lost a value as an indicator of default probability of Japanese banks, is basically confirmed. However, it is important to stress that the Japan premium and stock prices do react to changes in CDS that is a direct measure of default probability of Japanese banks. Although the magnitude of CDS as well as that of the Japan premium has been lower in 2001-2002, compared to in 1998, this does not necessarily mean that reputations of Japanese banks have been recovered. The stock and the interbank markets do react to the changes in the pricing of default risk of Japanese banks, although with lower sensitivity.

Insert Tables 6-2 and 6-3 about here

\section{Concluding Remarks}


In this paper we have exploited a newly collected data of credit derivative spread. Since it is suspected that the Japan Premium no longer represents default risk of Japanese banks, credit derivative spread, CDS, is a more direct, better measure. Examining the correlation between CDS and stock prices and the correlation between CDS and the Japan premium, it is found that the relationship between the three indicators are consistent with theoretical prediction. Higher CDS tends to be associated with lower stock prices and higher Japan premium. This relationship seems to hold both in time-series, with the magnitude of impact changing overtime, and in cross-section. This result is robust with respect to different methods of panel regressions or the sample period.

One of the salient results of this paper is that the sensitivity of the Japan premium to credit risk is much lower in 2001-2002, compared to in 1998 . This should be an alarm to any research economist who may want to use the Japan premium data for the period after 2000. The LIBOR market seems to believe that even in the event of a bank failure in Japan, the interbank liability will be paid off either by collaterals or by the regulator. 


\section{Reference}

Cargill, T. (2000).“What Caused Japan’s Banking Crisis?,” in Hoshi, T. and Patrick, H. (eds), Crisis and Change in the Japanese Financial System, 37-58, Kluwer Academic Publishers, Massachusetts.

Hanajiri, T. (1999). "Three Japan Premiums in Autumn 1997 and Autumn 1998-----Why did premiums differ between markets?-------," Financial Markets Department Working Paper Series 99-E-1, Bank of Japan.

Horiuchi, A. (1999a). "Financial Fragility and Recent Developments in the Japanese Safety Net," in Bos, T. and Fetherston, A. T. (eds), Advances in Pacific Basin Financial Markets, Vol.3, 45-72, JAI Press.

Horiuchi, A. (1999b). "Japan's Bank Crisis: An Overview from Governance Perspectives," mimeograph.

Ito, T. and K. Harada (2000). "Japan Premium and Stock Prices: Two Mirrors of Japanese Banking Crises,” NBER Working Papers Series, No.7997, November.

Kashyap A. K. (2002). “Sorting Out Japan's Financial Crisis,” NBER Working Papers Series, No.9384, December.

Neal, S.R. (1996). "Credit Derivatives: New Financial Instruments for Controlling Credit Risk", FRB Kansas City.

Peek, J. and Rosengren, E.S..(2001). "Determinants of the Japan premium: Actions speak louder than words,” Journal of International Economics 53, 283-305. 
Posen, A. (2001). "Unchanging Innovation and Changing Economic Performance in Japan," in Steil, Victor \& Nelson. (eds), Technological Innovation and Economic Performance, 74-111, Princeton University Press.

Saito, M. and Shiratsuka, S. (2001). "Financial crises as the failure of arbitrage: Implications for monetary policy," Monetary and Economic Studies Special Eddition, 239-270.

Sato, R, R.V. Ramachandran and B. Kang (1990). "Risk Adjusted Deposit Insurance for Japanese Banks,” NBER Working Papers Series, No.3314, April.

Ueda, K. (2000). "Causes of Japan's Banking Problems in the 1990s," in Hoshi, T. and Patrick, H. (eds), Crisis and Change in the Japanese Financial System, 59-81, Kluwer Academic Publishers, Massachusetts. 
Figure1-1 DKB indicators

$\rightarrow$ Stock - LIBOR3 - CDS

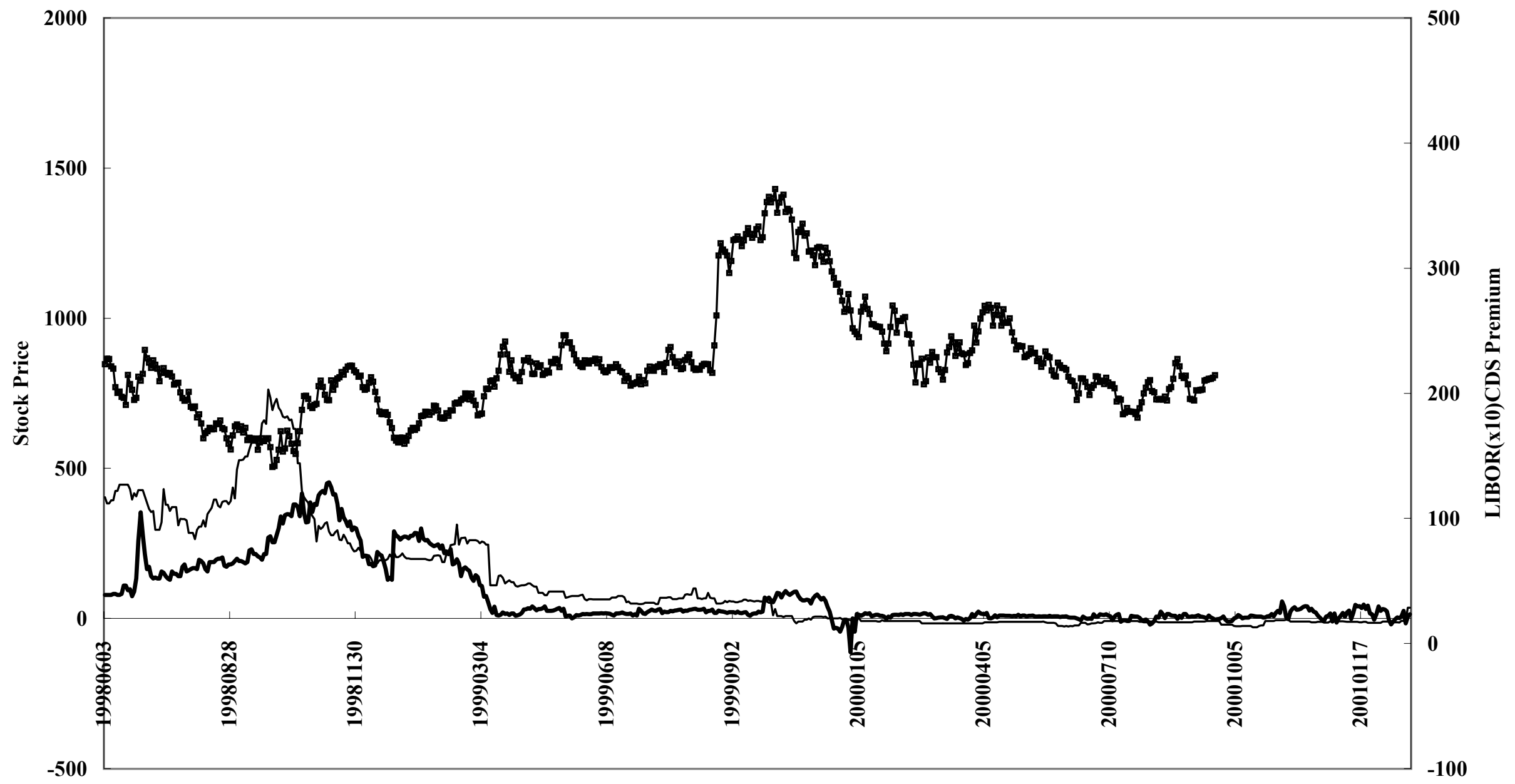


Figure1-2 IBJ indicators

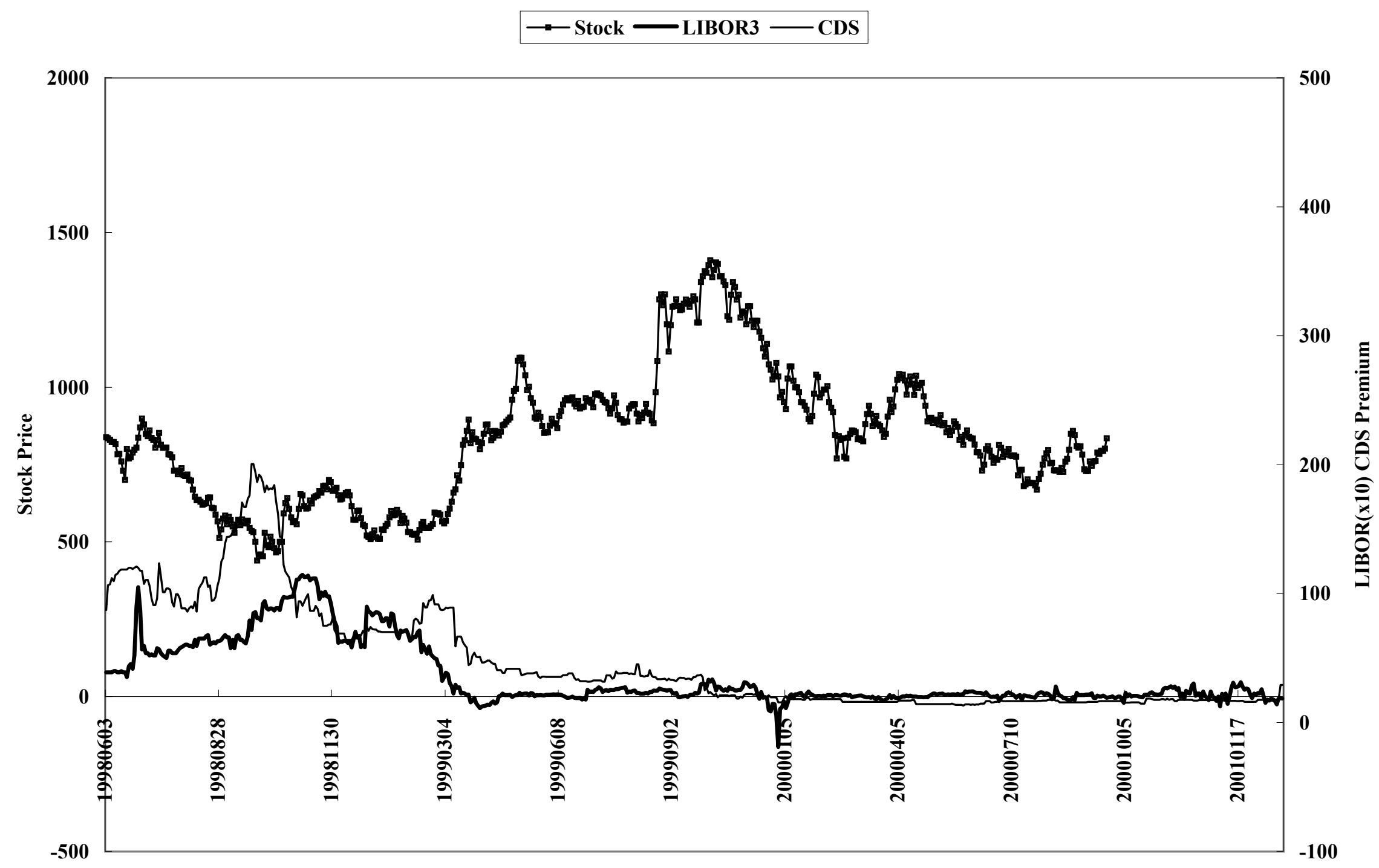


Figure1-3 FUJI Bank Indicators

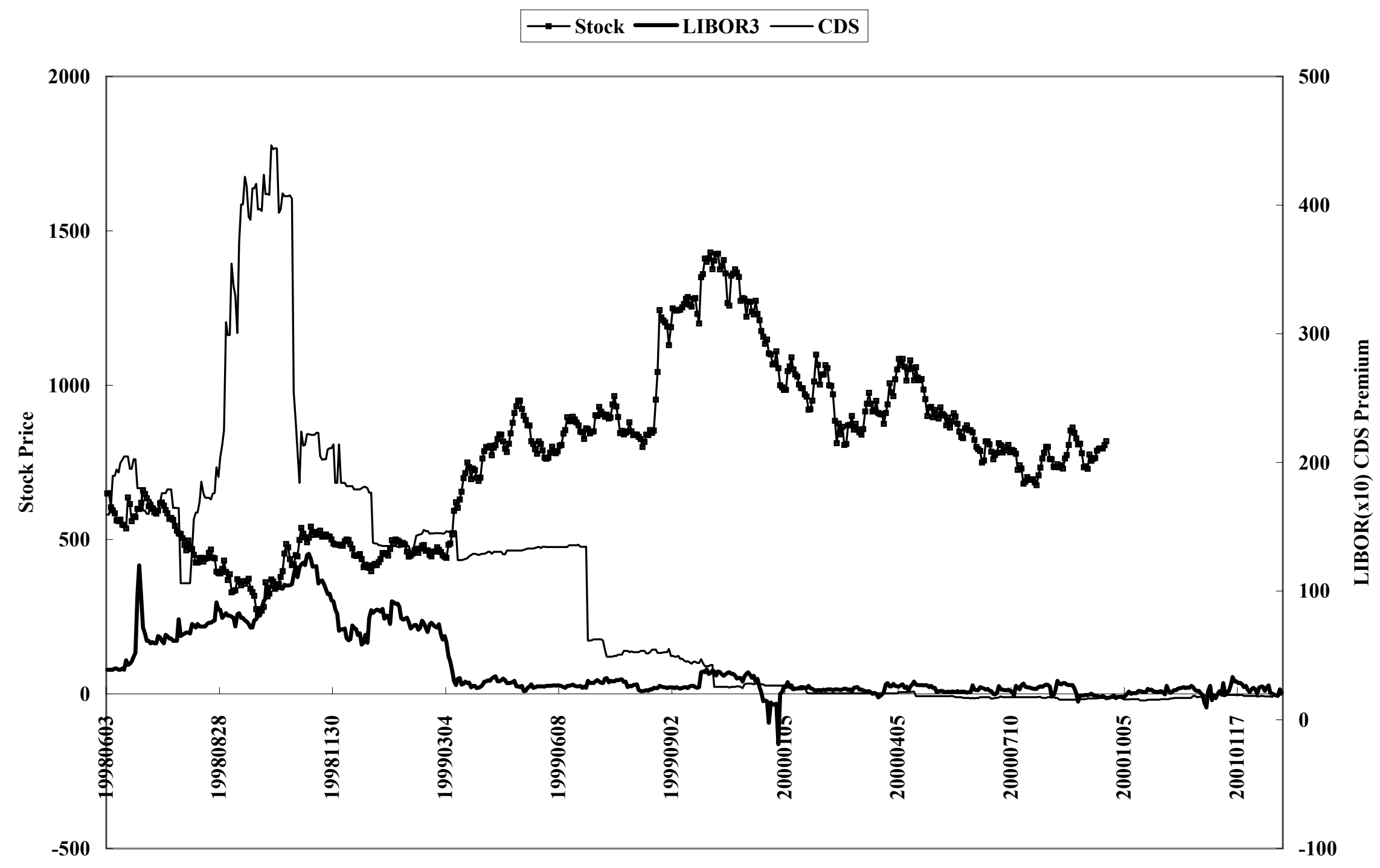


Figure1-4 BTM Indicators

$\rightarrow-$ Stock $\longrightarrow$ LIBOR3 - CDS

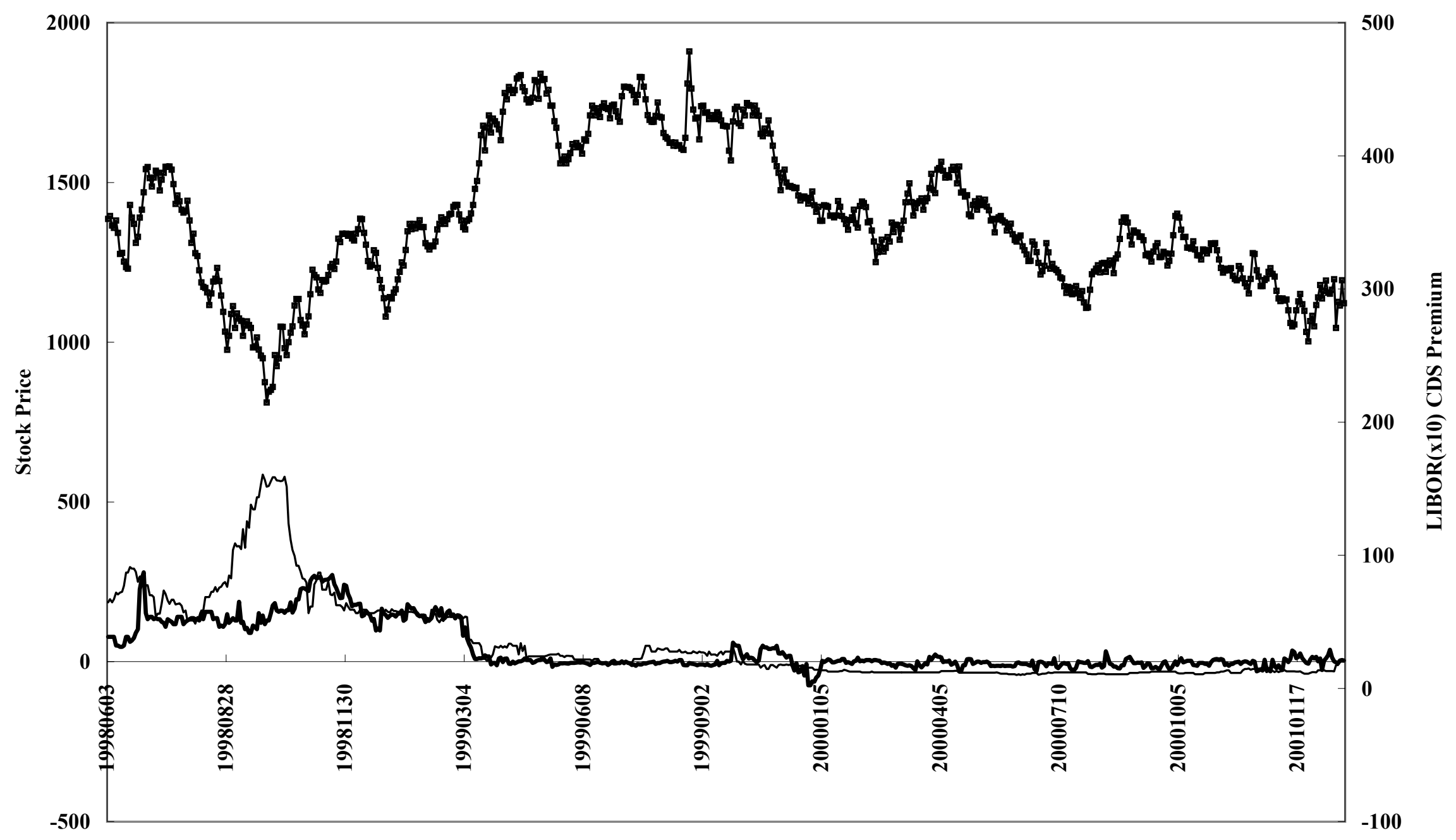


Figure1-5 Sanwa Bank Indicators

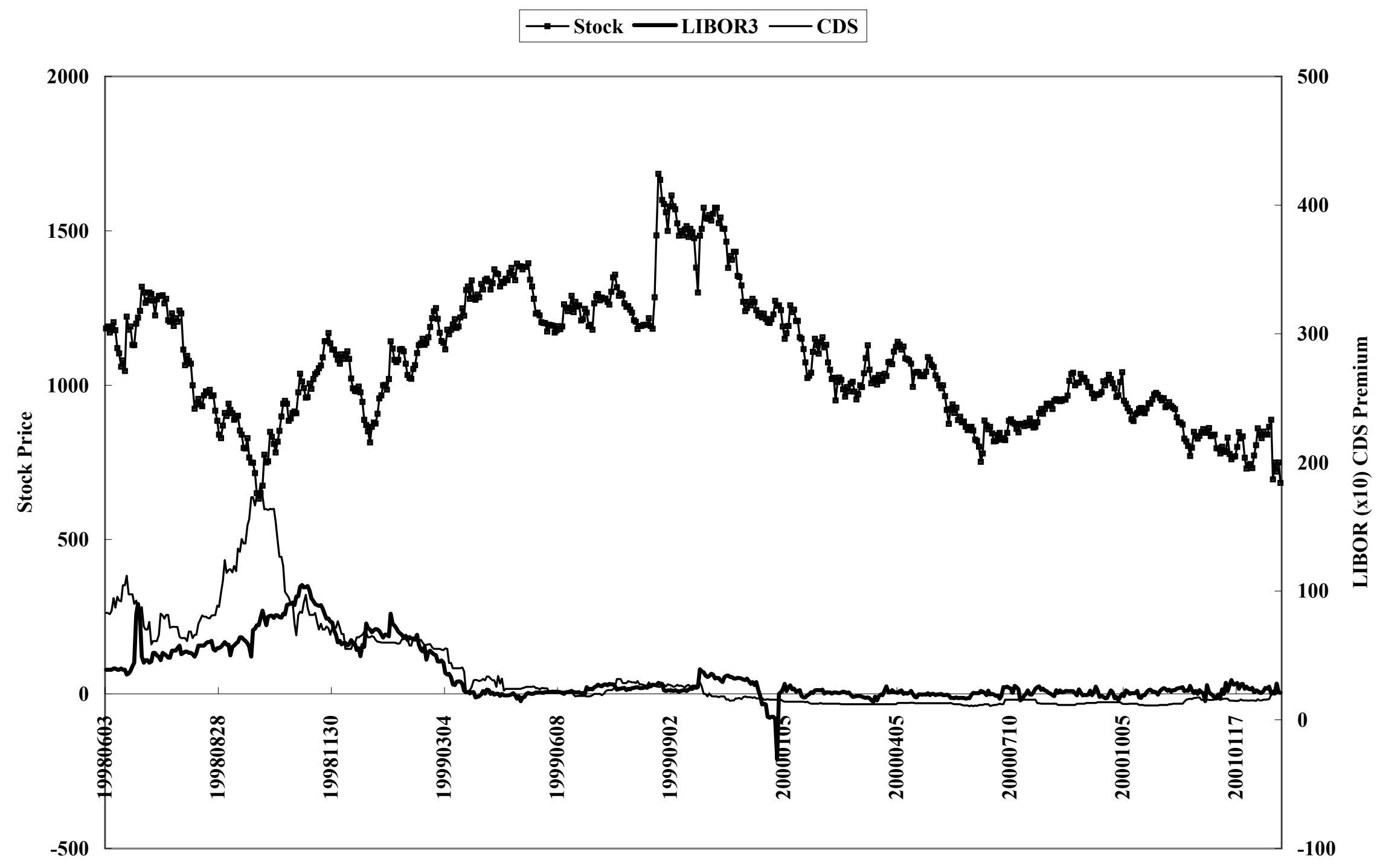


Figure1-6 Sumitomo Bank Indicators

$\rightarrow$ Stock - LIBOR3 - CDS

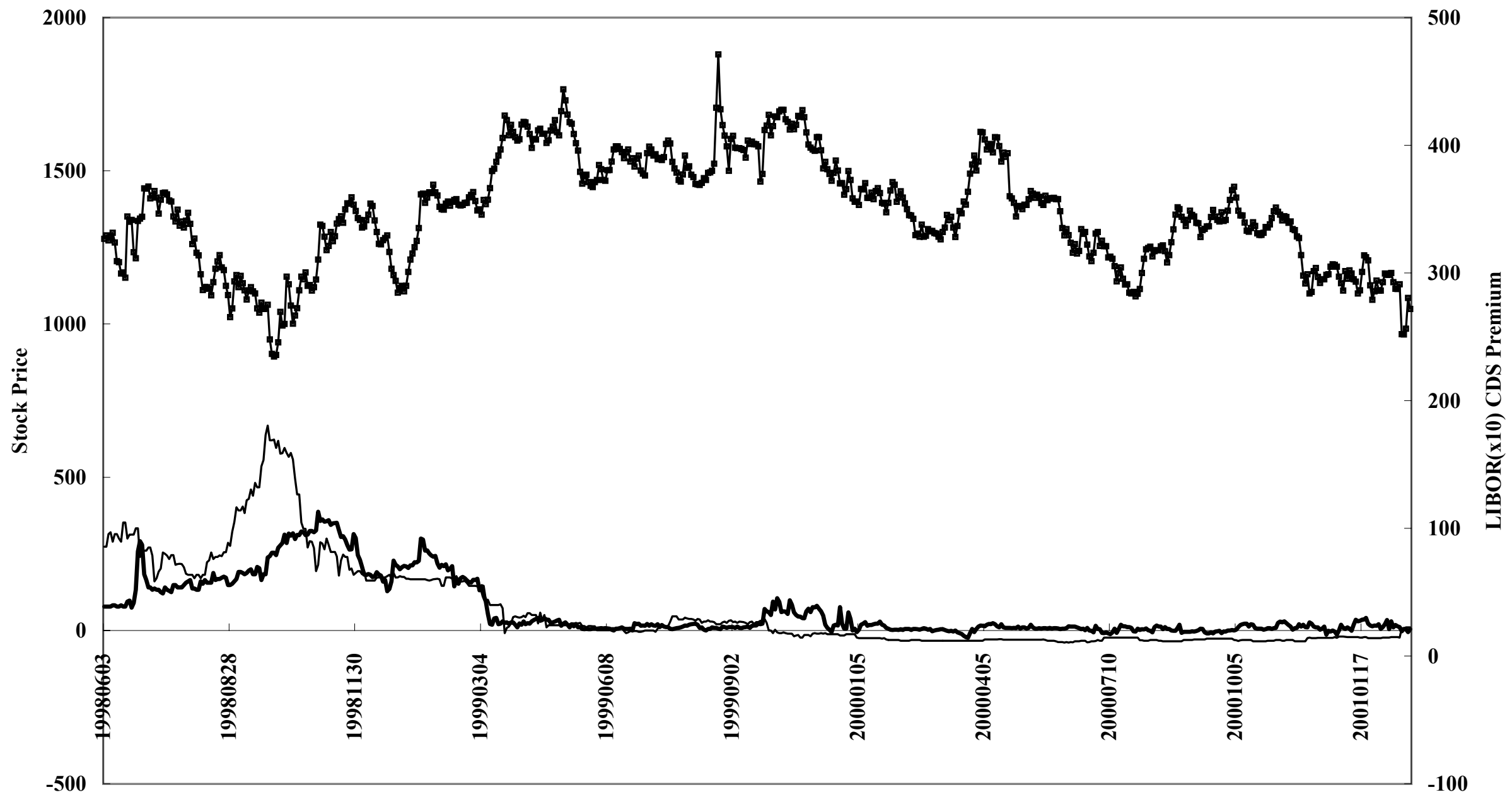


Figure2-1 MizuhoHD Indicators

$\rightarrow$ stock - LIBOR3 - CDS

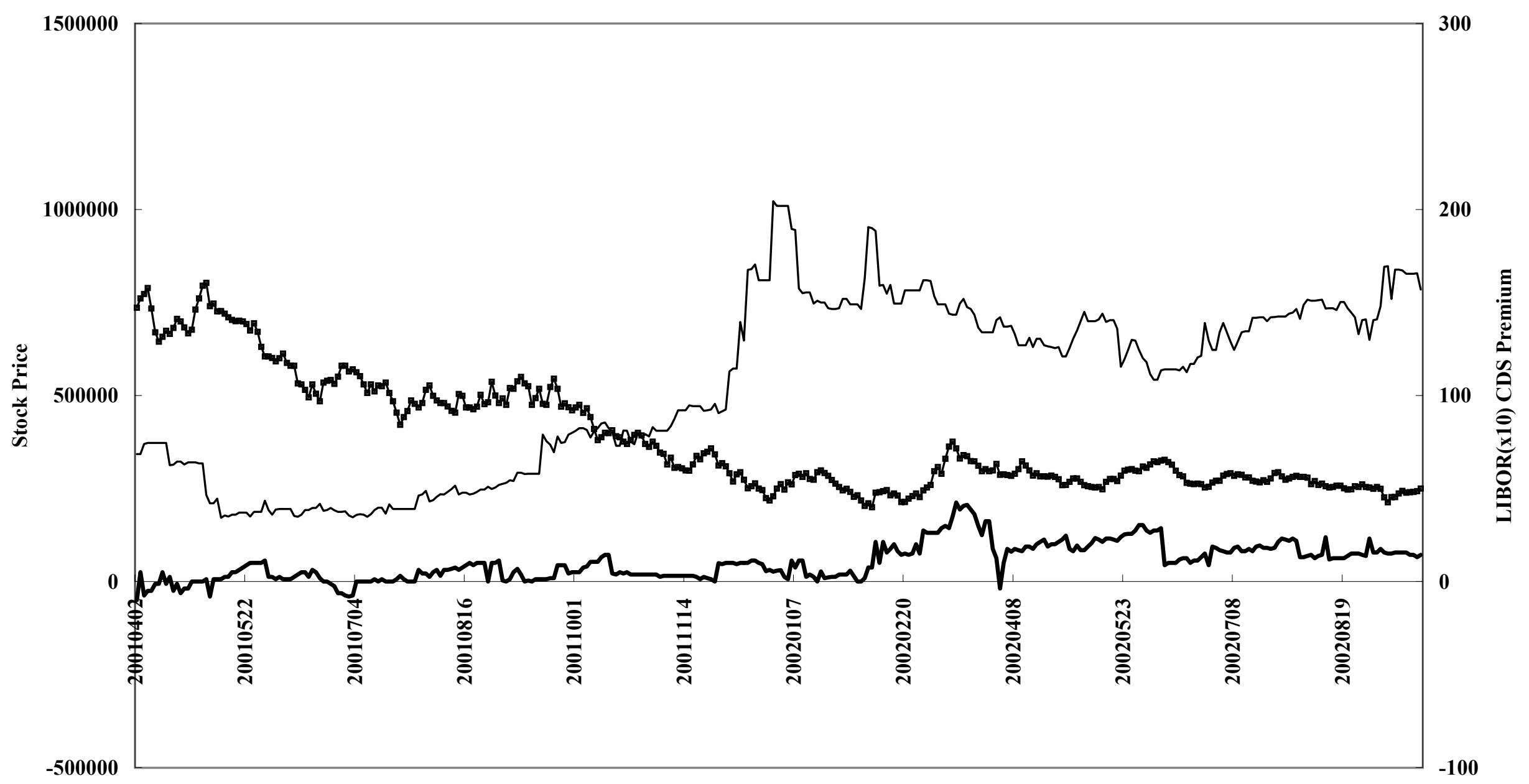


Figure2-2 Mitsubishi Tokyo FG Indicators

$$
\rightarrow \text { stock }- \text { LIBOR3 - CDS }
$$

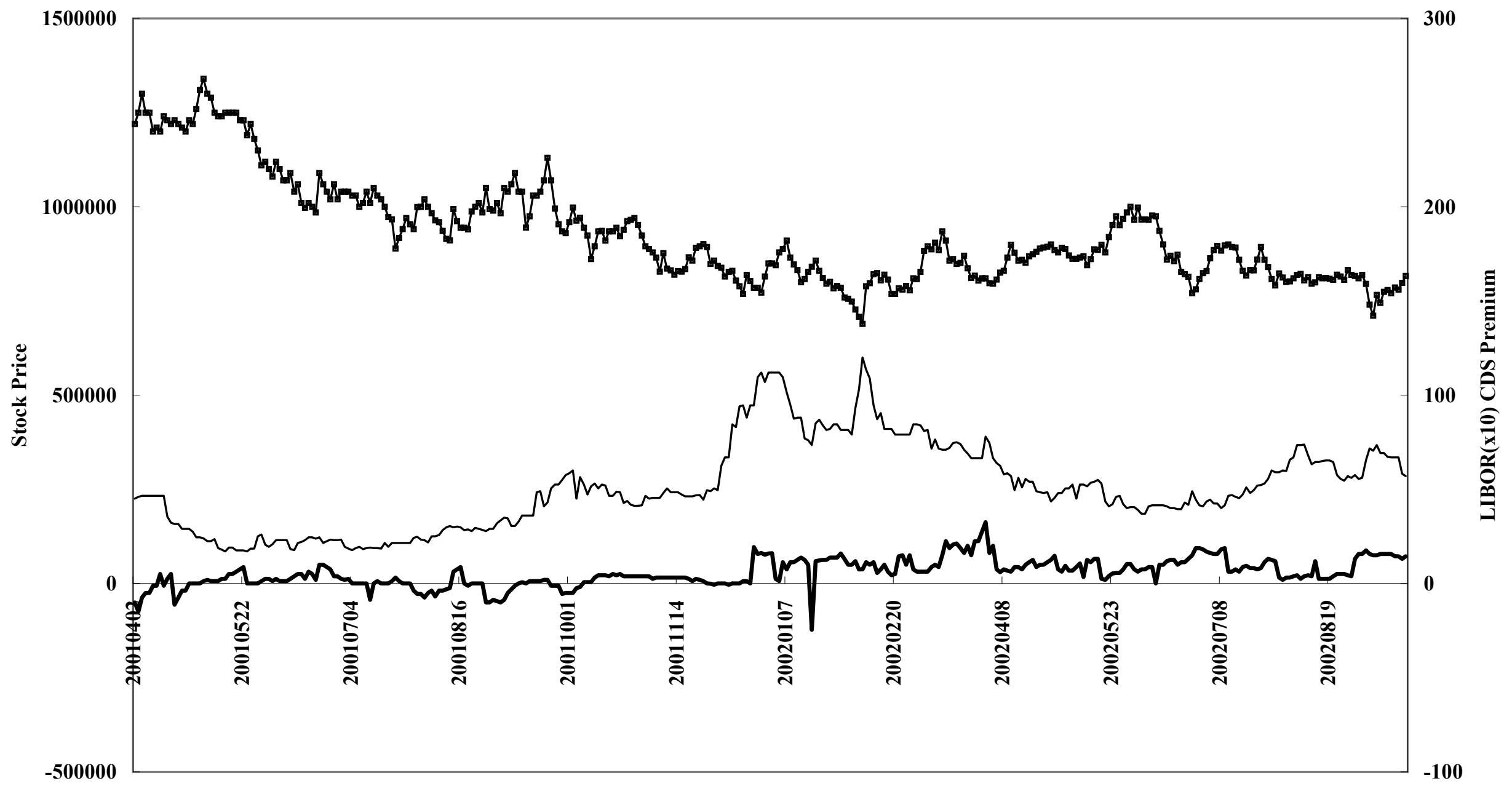


Figure2-3 UFJ Indicators

$\longrightarrow$ stock - LIBOR3 - CDS

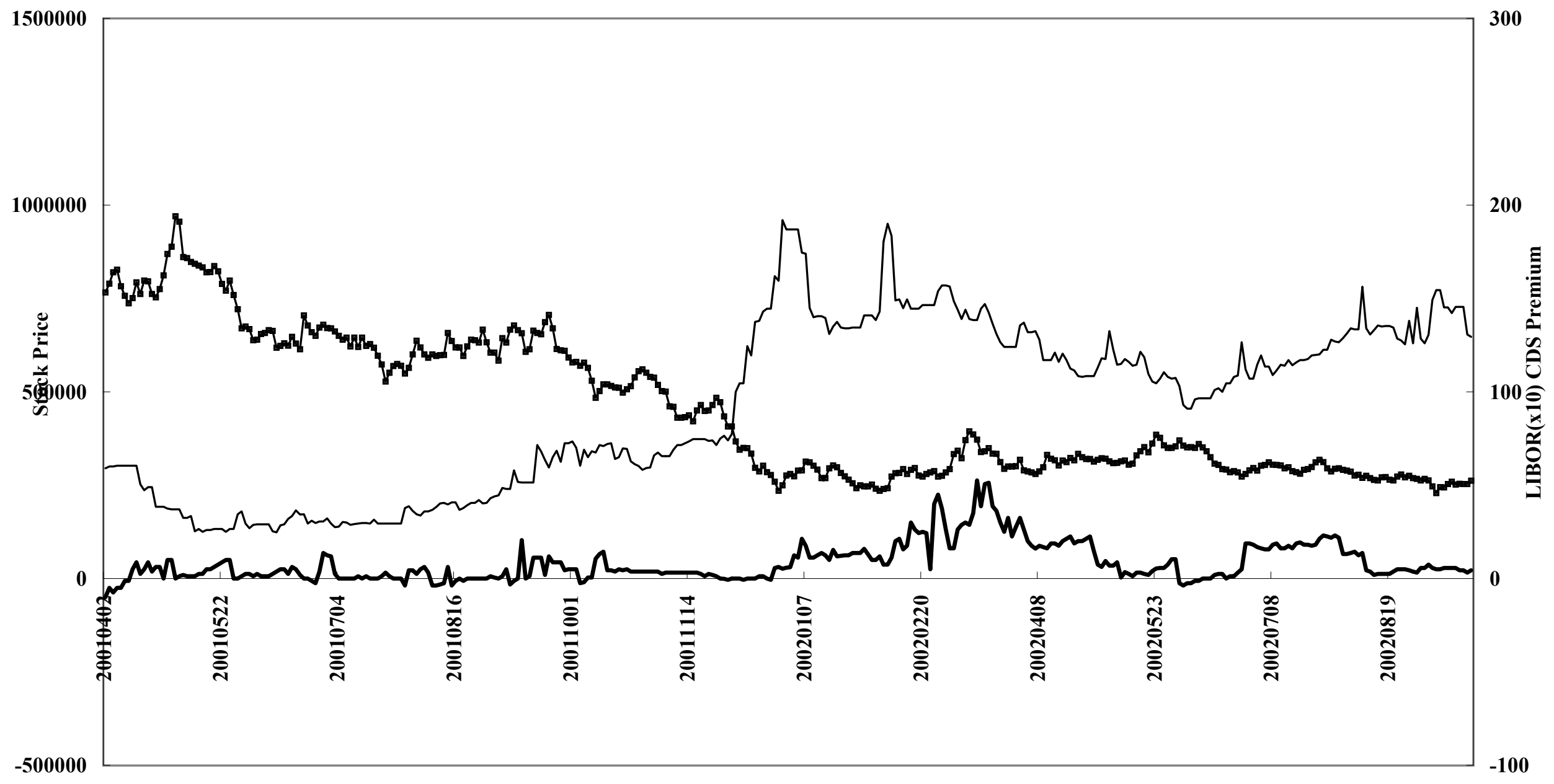


Figure2-4 Sumitomo Mitsui BC Indicators

$\longrightarrow$ stock $\longrightarrow$ LIBOR3 $\longrightarrow$ CDS

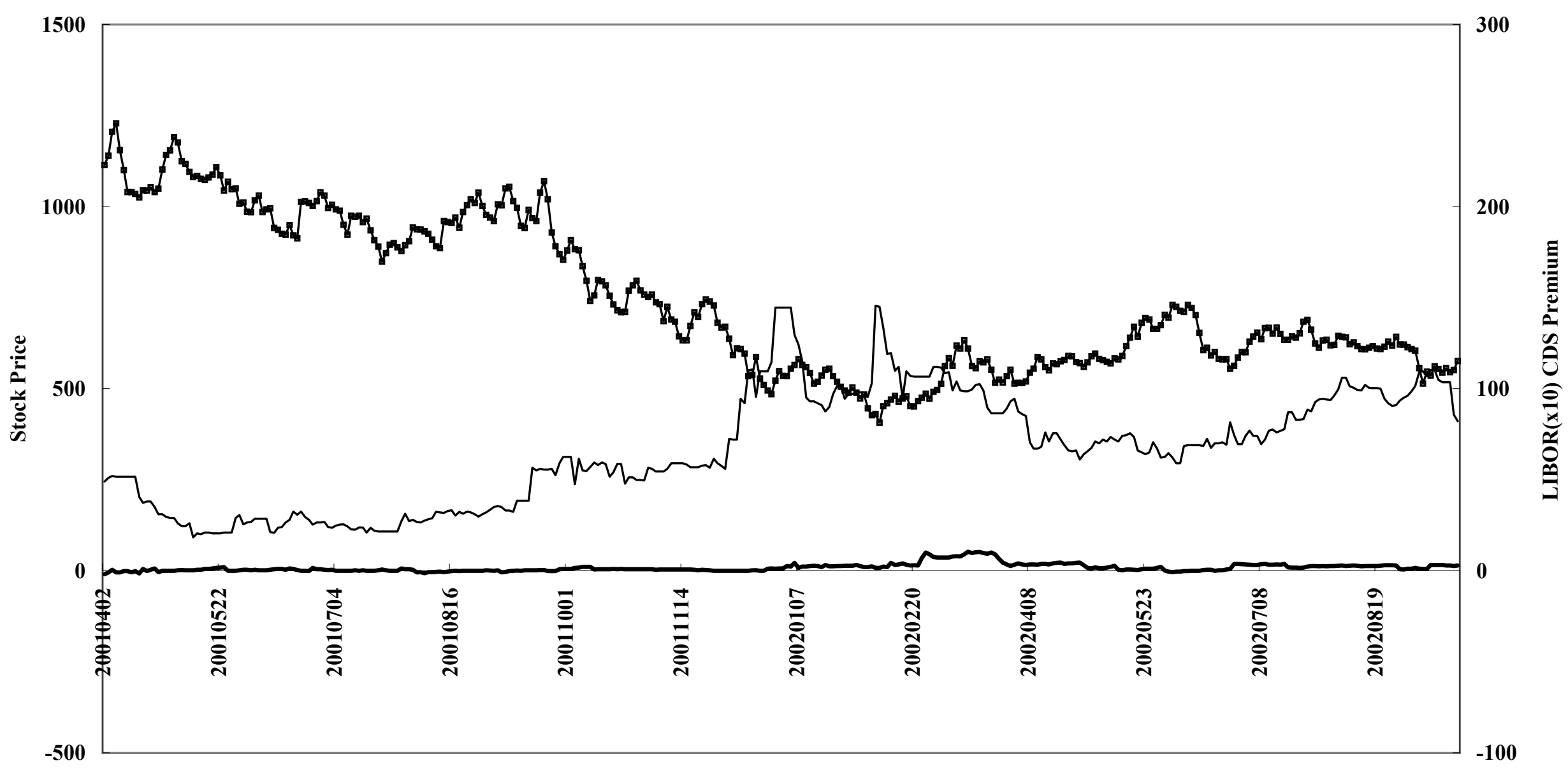




\begin{tabular}{|l|l|l|}
\hline \multicolumn{3}{|l|}{ Table 1: Correspondence of banks before and after mergers and reorganization } \\
\hline $\begin{array}{l}\text { First half } \\
\text { June 1998-Sept 1999 }\end{array}$ & $\begin{array}{l}\text { Second half } \\
\text { April 2001 - Sept 2002 }\end{array}$ & Comments: \\
\hline $\begin{array}{l}\text { DKB (Fig 1-1) } \\
\text { IBJ (Fig. 1-2) } \\
\text { Fuji (Fig. 1-3) }\end{array}$ & $\begin{array}{l}\text { Mizuho (Fig. 2-1) } \\
\text { Listed Sept 2000 }\end{array}$ & $\begin{array}{l}\text { The three banks reorganized among themselves to form Mizuho Bank (individual customers), } \\
\text { Mizuho Corporate (corporate customers); and Mizuho Asset Trust \& Banking (Trust Bank). } \\
\text { Mizuho in the sample is the holding company that hold these financial institutions. }\end{array}$ \\
\hline $\begin{array}{l}\text { Tokyo Mitsubishi } \\
\text { (Fig 1-4) }\end{array}$ & $\begin{array}{l}\text { Mitsubishi Tokyo } \\
\text { Financial Group (Fig. 2- } \\
\text { 2) Listed April 2001 }\end{array}$ & $\begin{array}{l}\text { MTFG is the financial holding company that owns the Tokyo Mitsubishi Bank, Mitsubishi } \\
\text { Trust and Bank, Nippon Trust and Banking and the Tokyo Trust. Later the three trust banks }\end{array}$ \\
\hline $\begin{array}{l}\text { Sanwa (Fig. 1-5) } \\
\text { merged into one } \\
\text { Fig 1-6) }\end{array}$ & $\begin{array}{l}\text { UFJ Group (Fig 2-3) } \\
\text { Listed April 2001 }\end{array}$ & $\begin{array}{l}\text { UFJ Group holding company has the former Sanwa Bank, Tokai Bank, and Toyo Trust and } \\
\text { Bank.. }\end{array}$ \\
\hline
\end{tabular}




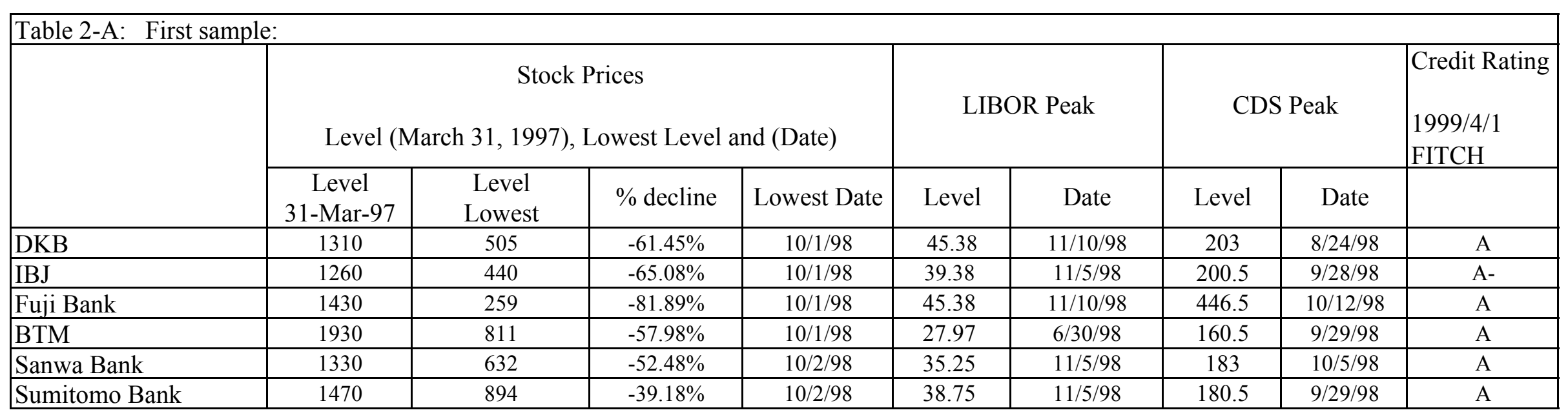

\begin{tabular}{|c|c|c|c|c|c|c|c|c|c|}
\hline \multirow{2}{*}{ Table 2-B: Second sa } & \multicolumn{4}{|c|}{$\begin{array}{c}\text { Stock Prices } \\
\text { Level (April 2, 2001), Lowest Level and (Date) }\end{array}$} & \multicolumn{2}{|c|}{ LIBOR Peak } & \multicolumn{2}{|c|}{ CDS Peak } & \multirow[t]{2}{*}{$\begin{array}{l}\text { Credit rating } \\
\text { 2001/4/1 } \\
\text { FITCH } \\
\end{array}$} \\
\hline & $\begin{array}{c}\text { Level } \\
\text { 2-Apr-01 }\end{array}$ & $\begin{array}{c}\text { Level, Lowest } \\
\text { in the spring of } \\
2002\end{array}$ & $\%$ decline & Lowest Date & Level & Date & Level & Date & \\
\hline Mizuho HD & 736000 & 200000 & $-72.83 \%$ & $2 / 6 / 02$ & 5.25 & $3 / 12 / 02$ & 204.5 & $12 / 19 / 01$ & $\mathrm{~A}$ \\
\hline Mitsubishi Tokyo FG & 1220000 & 689000 & $-43.52 \%$ & $2 / 6 / 02$ & 3.25 & $3 / 28 / 02$ & 120 & $2 / 6 / 02$ & $\mathrm{~A}^{+}$ \\
\hline UFJ HD & 766000 & 229000 & $-70.10 \%$ & $4 / 5 / 01$ & 5.25 & $12 / 19 / 01$ & 192 & $12 / 19 / 01$ & $\mathrm{~A}$ \\
\hline SMBC & 1114 & 407 & $-63.46 \%$ & $2 / 6 / 02$ & 4.25 & $3 / 12 / 02$ & 145.5 & $2 / 5 / 02$ & $\mathrm{~A}$ \\
\hline
\end{tabular}


Table3 Statistics Summary

\begin{tabular}{|c|c|c|c|c|c|c|c|c|c|c|c|c|c|c|c|}
\hline \multirow[t]{2}{*}{ First half } & \multicolumn{5}{|c|}{ Stock price } & \multicolumn{5}{|c|}{ LIBOR } & \multicolumn{5}{|c|}{ CDS } \\
\hline & Average & Range & s.d. & Min. & Max. & Average & Range & s.d. & Min. & Max. & Average & Range & s.d. & Min. & Max. \\
\hline DKB & 847 & 925 & 184 & 505 & $5 \quad 1430$ & 8.77 & 56.62 & 11.35 & -11.25 & 45.37 & 52.65 & 189.50 & 43.59 & 13.50 & 203.00 \\
\hline IBJ & 836 & 970 & 214 & 440 & 1410 & 7.47 & 55.62 & 10.86 & -16.25 & 39.37 & 52.61 & 187.50 & 43.61 & 13.00 & 200.50 \\
\hline Fuji Bank & 772 & 1171 & 271 & 259 & 1430 & 9.83 & 61.62 & 11.69 & -16.25 & 45.37 & 106.02 & 431.00 & 102.37 & 15.50 & 446.50 \\
\hline Bank of Tokyo Mitsubishi & 1419 & 1099 & 224 & 811 & 1910 & 4.99 & 35.38 & 7.93 & -7.42 & 27.96 & 38.07 & 150.50 & 33.70 & 10.00 & 160.50 \\
\hline Sanwa Bank & 1116 & 1053 & 198 & 632 & 1685 & 6.67 & 56.50 & 9.24 & -21.25 & 35.25 & 41.29 & 172.50 & 37.32 & 10.50 & 183.00 \\
\hline Sumitomo Bank & 1387 & 986 & 174 & 894 & 1880 & 7.93 & 41.12 & 10.07 & -2.37 & 38.75 & 40.96 & 170.00 & 36.72 & 10.50 & 180.50 \\
\hline Second half & \multicolumn{5}{|c|}{ Stock price } & \multicolumn{5}{|c|}{ LIBOR } & \multicolumn{5}{|c|}{ CDS } \\
\hline & Average & Range & s.d. & Min. & Max. & Average & Range & s.d. & Min. & Max. & Average & Range & s.d. & Min. & Max. \\
\hline Mizuho HD & 385167 & 603000 & 151467 & 200000 & 803000 & 1.03 & 5.25 & 0.97 & -1.00 & 4.25 & 104.56 & 170.25 & 46.84 & 34.25 & 204.50 \\
\hline Mitsubishi Tokyo FG & 928292 & 651000 & 135726 & 689000 & 1340000 & 0.56 & 5.71 & 0.72 & -2.46 & 3.25 & 50.71 & 103.00 & 23.26 & 17.00 & 120.00 \\
\hline UFJ HD & 453136 & 741000 & 187461 & 229000 & 970000 & 0.83 & 6.25 & 1.00 & -1.00 & 5.25 & 91.73 & 167.25 & 45.47 & 24.75 & 192.00 \\
\hline SMBC & 742 & 822 & 205 & 407 & 1229 & 0.83 & 6.25 & 1.11 & -1.00 & 5.25 & 66.32 & 127.25 & 31.28 & 18.25 & 145.50 \\
\hline
\end{tabular}


Table 4 Correlation of $(\log ($ stock $)-\log ($ TOPIX) $)$ and CDS

\begin{tabular}{|c|c|c|c|c|c|c|c|}
\hline & days & DKB(Mizuho & IBJ(Mizuho) & Fuji(Mizuho) & BTM & Sanwa (UFJ) & SumitomoMits \\
\hline June 1998-Sept 1999 & 315 & -0.588 & -0.686 & -0.76 & -0.88 & -0.763 & -0.793 \\
\hline Oct 1999 - Sept 2000 & 216 & 0.662 & 0.7 & 0.81 & 0.713 & 0.705 & 0.557 \\
\hline April 2001 - Sept 2002 & 352 & & -0.807 & & -0.283 & -0.903 & -0.821 \\
\hline
\end{tabular}

Table 5 Correlation of LIBOR 3M and CDS

\begin{tabular}{|l|c|c|c|c|c|c|c|}
\hline & days & DKB(Mizuho & IBJ(Mizuho) & Fuji(Mizuho) & BTM & Sanwa (UFJ) & SumitomoMits \\
\hline June 1998-Sept 1999 & 315 & 0.656 & 0.655 & 0.661 & 0.651 & 0.719 & 0.724 \\
\hline Oct 1999 - Sept 2000 & 216 & 0.501 & 0.362 & 0.394 & 0.432 & 0.431 & 0.704 \\
\hline April 2001 - Sept 2002 & 352 & \multicolumn{7}{|c|}{0.556} & 0.451 & 0.529 & 0.583 \\
\hline
\end{tabular}


Table 6-1 Panel Analysis; Fixed effect

\begin{tabular}{lcc}
\hline First Half & JP & STOCK \\
\hline Variable & $(1)$ & $(2)$ \\
\hline CDS & $0.101^{* * *}$ & $-0.0003^{* * *}$ \\
CALL & $(0.00269)^{* * *}$ & $(0.00003)^{* * *}$ \\
& $21.858^{* * *}$ & $0.043^{* * *}$ \\
& $(1.02847)^{*}$ & $(0.012244)$ \\
R2 & $0.593498^{* * *}$ & 0.678364 \\
F1 & $41.238^{* * *}$ & $72.446^{* * *}$ \\
F2 & $30.491^{* * *}$ & $1058.4^{* * *}$ \\
\hline
\end{tabular}

Asterisks $* * *, * *$ and $*$ denote the significance at $1 \%, 5 \%$ and $10 \%$ level respectively.

\begin{tabular}{lcc}
\hline Second Half & JP & STOCK \\
\hline Variable & $(1)$ & $(2)$ \\
\hline CDS & $0.013^{* * *}$ & $-0.001^{* * *}$ \\
CALL & $(0.00064)$ & $(0.000034)$ \\
& $-4.839^{* *}$ & -0.113 \\
R2 & $2.24037^{*}$ & $(0.119043)$ \\
F1 & $0.304329^{* * *}$ & 0.998799 \\
F2 & $4.9716^{* * *}$ & $198.76^{* * *}$ \\
\end{tabular}

Asterisks $* * * * *$ and $*$ denote the significance at $1 \%, 5 \%$ and $10 \%$ level respectively. 
Table 6-2 Pooled OLS

\begin{tabular}{lcc}
\hline First Half & JP & STOCK \\
\hline Variable & $(1)$ & $(2)$ \\
\hline Intercept & $-0.463^{* * *}$ & $-0.103^{* * *}$ \\
CDS & $(0.1726)^{* * *}$ & $(0.00328)$ \\
& $0.089^{* * *}$ & $-0.001^{* * *}$ \\
CALL & $(0.0024)^{* * *}$ & $(0.000046)$ \\
& $24.485^{* * *}$ & $0.211^{* * *}$ \\
R2 & $(1.0083)$ & $(0.0192)$ \\
F statistics & $0.574^{* * *}$ & $0.142^{* * *}$ \\
\hline
\end{tabular}

Asterisks $* * *, * *$ and $*$ denote the significance at $1 \%, 5 \%$ and $10 \%$ level respectively.

\begin{tabular}{lcc}
\hline Second Half & JP & STOCK \\
\hline Variable & $(1)$ & $(2)$ \\
\hline Intercept & -0.248 & $2.398^{* * *}$ \\
CDS & $(0.0540)$ & $(0.0816)$ \\
& $0.011^{* * *}$ & $0.002^{* * *}$ \\
CALL & $(0.00055)^{* * *}$ & $(0.00083)^{*}$ \\
& $-7.254^{* * *}$ & $5.842^{*}$ \\
R2 & $(2.201)$ & $(3.3251)^{*}$ \\
F statistics & $0.288^{* * *}$ & 0.007 \\
\hline Astisks & $6.9767^{* * *}$ & $23771^{* * *}$ \\
\hline
\end{tabular}

Asterisks $* * *, * *$ and $*$ denote the significance at $1 \%, 5 \%$ and $10 \%$ level respectively. 
Table 6-3 Panel Analysis; Random effect

\begin{tabular}{lcc}
\hline First Half & JP & STOCK \\
\hline Variable & $(1)$ & $(2)$ \\
\hline Intercept & -0.738 & $-0.122 * * *$ \\
CDS & $(0.6076)$ & $(0.0416)$ \\
& $0.100 * * *$ & $-0.0003 * * *$ \\
CALL & $(0.00267)$ & $(0.000032)$ \\
& $21.989 * * *$ & $0.043 * * *$ \\
R2 & $(1.0264)$ & $(0.012243)$ \\
Hausman test & 0.572290 & 0.136677 \\
\hline
\end{tabular}

Asterisks $* * * * *$ and $*$ denote the significance at $1 \%, 5 \%$ and $10 \%$ level respectively.

\begin{tabular}{lcc}
\hline Second Half & JP & STOCK \\
\hline Variable & $(1)$ & $(2)$ \\
\hline Intercept & $-0.139^{*}$ & $2.733^{* * *}$ \\
CDS & $(0.0841)$ & $(0.6231)$ \\
& $0.013^{* * *}$ & $-0.001 * * *$ \\
CALL & $(0.00063)$ & $(0.000034)$ \\
& $-5.221^{* *}$ & -0.113 \\
R2 & $(2.23067)$ & $(0.11904)$ \\
Hausman test & 0.287611 & 0.00457 \\
\hline
\end{tabular}

Asterisks $* * * * *$ and $*$ denote the significance at $1 \%, 5 \%$ and $10 \%$ level respectively. 


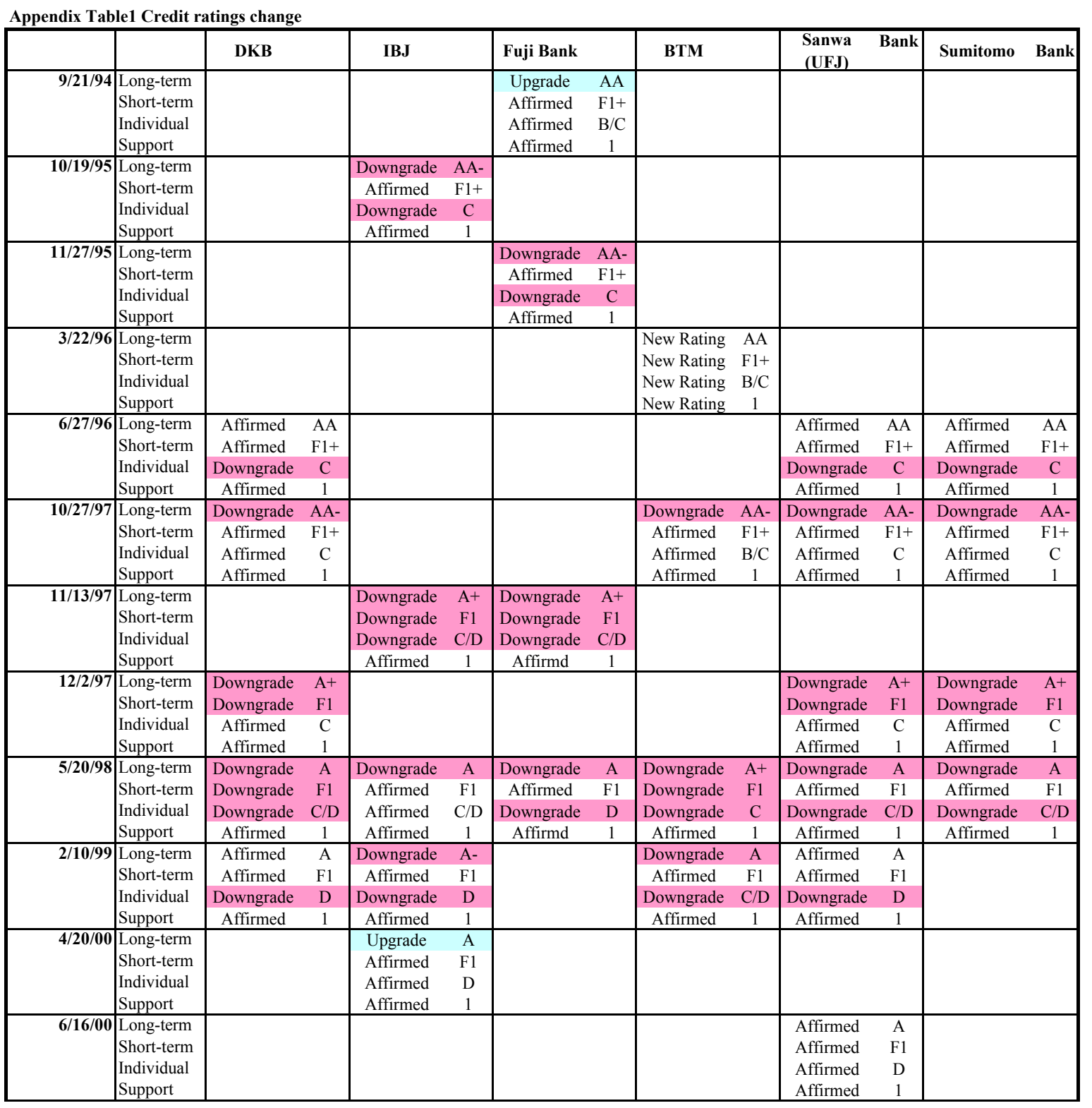




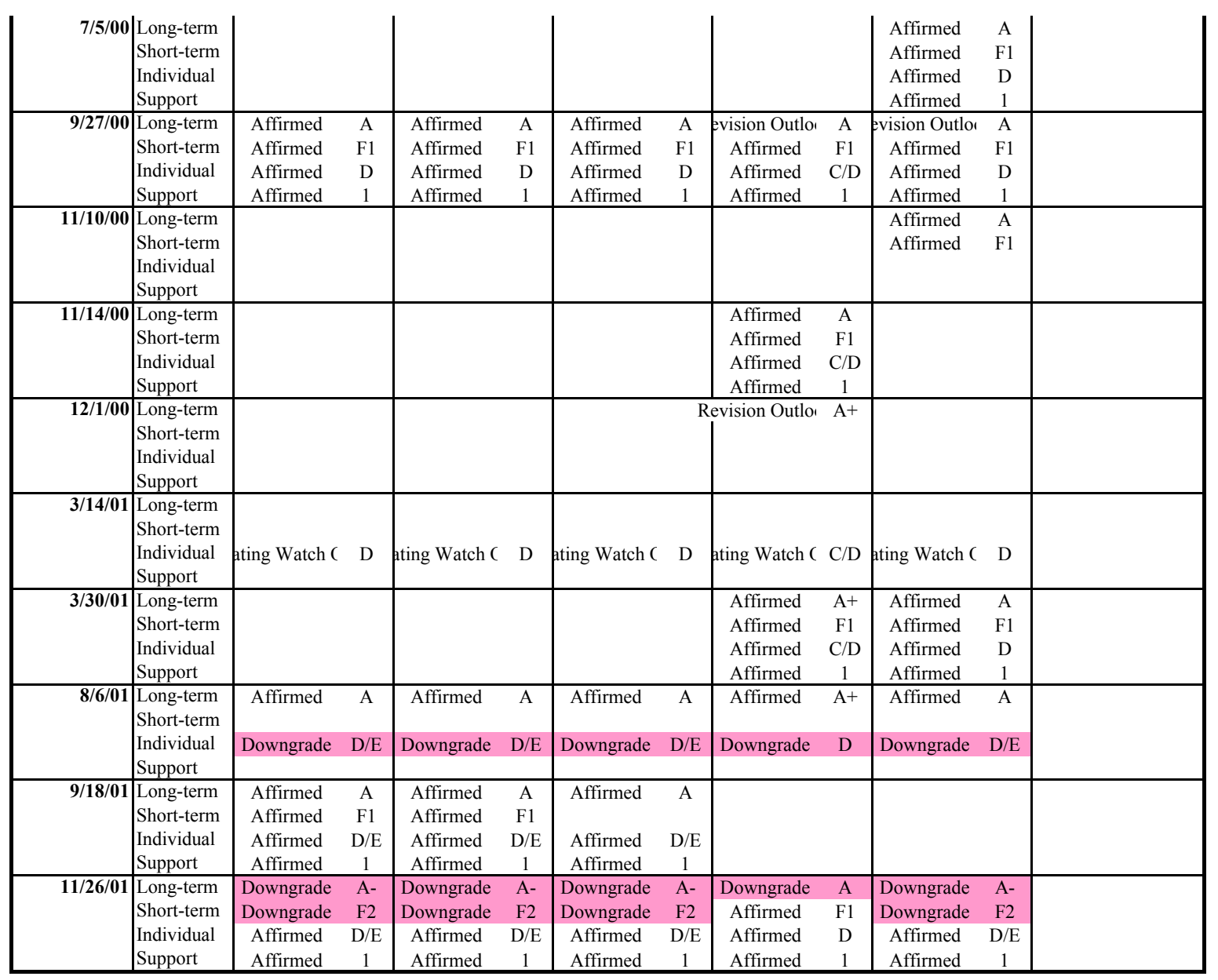

Ratings history data are obtained from the FITCH Ratings, that contains International long- and short term ratings, individual and support ratings. The below is based on the definition given by FITCH. Long- and short-term ratings assess its general creditworthiness on a senior basis.

The difference between long- and short- is the maturity of obligations. A short-term rating has a horizon of less than 12 months. Therefore short-term ratings place emphasis on the liquidity necessary.

The individual ratings assess how a bank would be viered if it were entirely independent and could not rely on ecternal support.

Individual ratings therefore are for management of risk, and the likelihood that it would run into significant difficulties.

Support ratings are not about the quality of a bank, but they are the assessment of whether the bank would receive support. 
Appendix2 Genuine Capital Ratio (at September 30,2001)

As percentage of weighted assets

\begin{tabular}{|c|c|c|c|c|c|c|}
\hline & Tier 1 capital & Publicfunds & Pref securities & Other pref.cap & Tax effect & Genuine Tier 1 \\
\hline $\mathrm{DKB}$ & $5.52 \%$ & $2.09 \%$ & $0.00 \%$ & $0.00 \%$ & $2.26 \%$ & $1.17 \%$ \\
\hline IBJ & $5.95 \%$ & $1.32 \%$ & $1.13 \%$ & $0.00 \%$ & $1.84 \%$ & $1.67 \%$ \\
\hline Fuji Bank & $4.73 \%$ & $1.94 \%$ & $0.48 \%$ & $0.38 \%$ & $2.39 \%$ & $-0.45 \%$ \\
\hline Bank of Tokyo Mitsubishi & $5.18 \%$ & $0.00 \%$ & $0.00 \%$ & $0.51 \%$ & $1.80 \%$ & $2.87 \%$ \\
\hline Sanwa Bank & $5.45 \%$ & $1.80 \%$ & $0.54 \%$ & $0.45 \%$ & $1.94 \%$ & $0.73 \%$ \\
\hline Sumitomo Bank & $6.04 \%$ & $1.93 \%$ & $1.24 \%$ & $0.00 \%$ & $2.51 \%$ & $0.37 \%$ \\
\hline
\end{tabular}

* "Genuine"Tier 1 capital excludes preferred instruments and tax effect.

Source: Fitch Ratings. 
Appendix3 Genuine Capital Ratio (at September 30,2002)

As percentage of weighted assets

\begin{tabular}{|c|c|c|c|c|}
\hline & Tier 1 capital & Excluding $90 \%$ of Tax Effec 1 & Less Public Fund & GenuineTier1* \\
\hline Mizuho HD & $5.27 \%$ & $3 \%$ & $0.45 \%$ & $-0.99 \%$ \\
\hline Mitsubishi Tokyo FG & $5.24 \%$ & $4 \%$ & $3.57 \%$ & $2.86 \%$ \\
\hline UFJ HD & $5.77 \%$ & $3 \%$ & $0.26 \%$ & $-1.83 \%$ \\
\hline SMBC & $5.37 \%$ & $3 \%$ & $0.45 \%$ & $-1.21 \%$ \\
\hline
\end{tabular}

* "Genuine"Tier 1 capital excludes preferred instruments and tax effect.

Source: Fitch Ratings. 
Appendix Table 4 Credit Derivative trading volume (principal amounts : million dollar)

\begin{tabular}{|c|c|c|c|c|c|c|}
\hline & June-99 & December-99 & June- 00 & December-00 & June-01 & December-01 \\
\hline OTC total volume & 11,159 & 16,538 & 14,691 & 13,281 & 14,309 & 17,432 \\
\hline 6-month growth (\%) & & $48.2 \%$ & $-11.2 \%$ & $-9.6 \%$ & $7.7 \%$ & $21.8 \%$ \\
\hline one-year growth (\%) & & & $31.6 \%$ & $-19.7 \%$ & $-2.6 \%$ & $31.3 \%$ \\
\hline Credit Default Swaps Total & 10,230 & 12,831 & 12,248 & 11,698 & 12,815 & 15,127 \\
\hline Credit Default Swaps (Selling) & 5,173 & 3,388 & 3,259 & 3,599 & 4,275 & 4,357 \\
\hline Credit Default Swaps (Buying) & 5,057 & 9,443 & 8,989 & 8,099 & 8,540 & 10,770 \\
\hline 6-month growth (\%) & & $25.4 \%$ & $-4.5 \%$ & $-4.5 \%$ & $9.5 \%$ & $18.0 \%$ \\
\hline one-year growth (\%) & & & $19.7 \%$ & $-8.8 \%$ & $4.6 \%$ & $29.3 \%$ \\
\hline Total Return Swaps Total & 338 & 2,707 & 1,630 & 956 & 888 & 1,269 \\
\hline Total Return Swaps (Selling) & 65 & 1,289 & 459 & & 19 & 175 \\
\hline Total Return Swaps (Buying) & 273 & 1418 & 1171 & 956 & 869 & 1,094 \\
\hline Credit Spread Total & 36 & 16 & & & & \\
\hline Credit Spread (Selling) & 36 & 16 & & & & \\
\hline \multicolumn{7}{|l|}{ Credit Spread (Buying) } \\
\hline Credit Link Note Total & 502 & 921 & 731 & 561 & 550 & 1,024 \\
\hline Credit Link Note (Issurance) & 270 & 629 & 591 & 561 & 144 & \\
\hline Credit Link Note (Purchase) & 232 & 292 & 140 & & 406 & 1,024 \\
\hline Others Total & 55 & 55 & 82 & 67 & 55 & 12 \\
\hline Others (Selling) & 55 & 55 & 55 & 55 & & 6 \\
\hline Others (Buying) & & & 27 & 12 & 55 & 6 \\
\hline
\end{tabular}

Source; BIS Derivative Survey(http://www.boj.or.jp/en/siryo/siryo_f.htm) 